\title{
Front Matter: Volume 7120
}

, "Front Matter: Volume 7120," Proc. SPIE 7120, Optical Fibers and Their Applications 2008, 712001 (13 June 2008); doi: 10.1117/12.804487

SPIE. Event: Optical Fibers and Their Applications 2008, 2008, Bialowieza, Poland 


\title{
PROCEEDINGS OF SPIE
}

\section{Optical Fibers and Their Applications 2008}

\author{
Jan Dorosz \\ Ryszard S. Romaniuk \\ Tomasz R. Woliński \\ Editors
}

30 January-2 February 2008

Białowieża, Poland

Organized by

Department of Optical Radiation, Białystok University of Technology (Poland)

Co-organized by

Committee of Electronics and Telecommunications, Polish Academy of Sciences (Poland) Ceramics Society of Poland (Poland)

Committee of Optoelectronics, Association of Polish Electrical Engineers (Poland)

Photonics Society of Poland (Poland)

Published by

SPIE

Volume 7120 
The papers included in this volume were part of the technical conference cited on the cover and title page. Papers were selected and subject to review by the editors and conference program committee. Some conference presentations may not be available for publication. The papers published in these proceedings reflect the work and thoughts of the authors and are published herein as submitted. The publisher is not responsible for the validity of the information or for any outcomes resulting from reliance thereon.

Please use the following format to cite material from this book:

Author(s), "Title of Paper," in Optical Fibers and Their Applications 2008, edited by Jan Dorosz, Ryszard S. Romaniuk, Tomasz R. Woliński, Proceedings of SPIE Vol. 7120 (SPIE, Bellingham, WA, 2008) Article CID Number.

ISSN 0277-786X

ISBN 9780819473530

Published by

SPIE

P.O. Box 10, Bellingham, Washington $98227-0010$ USA

Telephone +1 3606763290 (Pacific Time) · Fax +1 3606471445

SPIE.org

Copyright (c) 2008, Society of Photo-Optical Instrumentation Engineers

Copying of material in this book for internal or personal use, or for the internal or personal use of specific clients, beyond the fair use provisions granted by the U.S. Copyright Law is authorized by SPIE subject to payment of copying fees. The Transactional Reporting Service base fee for this volume is $\$ 18.00$ per article (or portion thereof), which should be paid directly to the Copyright Clearance Center (CCC), 222 Rosewood Drive, Danvers, MA 01923. Payment may also be made electronically through CCC Online at copyright.com. Other copying for republication, resale, advertising or promotion, or any form of systematic or multiple reproduction of any material in this book is prohibited except with permission in writing from the publisher. The CCC fee code is 0277-786X/08/\$18.00.

Printed in the United States of America.

Publication of record for individual papers is online in the SPIE Digital Library.

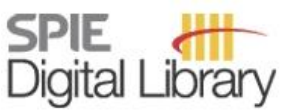

SPIEDigitalLibrary.org

Paper Numbering: Proceedings of SPIE follow an e-First publication model, with papers published first online and then in print and on CD-ROM. Papers are published as they are submitted and meet publication criteria. A unique, consistent, permanent citation identifier (CID) number is assigned to each article at the time of the first publication. Utilization of CIDs allows articles to be fully citable as soon they are published online, and connects the same identifier to all online, print, and electronic versions of the publication. SPIE uses a six-digit CID article numbering system in which:

- The first four digits correspond to the SPIE volume number.

- The last two digits indicate publication order within the volume using a Base 36 numbering system employing both numerals and letters. These two-number sets start with 00, 01, 02, 03, 04, 05, $06,07,08,09,0 \mathrm{~A}, 0 \mathrm{~B} \ldots \mathrm{OZ}$, followed by 10-1Z, 20-2Z, etc.

The CID number appears on each page of the manuscript. The complete citation is used on the first page, and an abbreviated version on subsequent pages. Numbers in the index correspond to the last two digits of the six-digit CID number. 


\title{
Contents
}

\author{
vii Conference Committee \\ ix Opening Address \\ xiii Introduction
}

\section{SESSION 1 THEORY OF OPTICAL FIBERS}

712002 Guided modes in photonic liquid crystal fibers [7120-01]

M. S. Chychłowski, K. A. Rutkowska, T. R. Woliński, Warsaw Univ. of Technology (Poland)

712003 Analyses of light propagation in photonic liquid crystal fibers [7120-02] K. A. Rutkowska, R. T. Rutkowski, M. S. Chychłowski, T. R. Woliński, Warsaw Univ. of Technology (Poland)

712004 Electric field control of liquid crystal infiltrated photonic crystal fibers by using various electrode configurations [7120-03]

S. Ertman, T. R. Woliński, Warsaw Univ. of Technology (Poland)

712005 Optical power evaluation by Hermite or Legendre polynomials in single-mode fiber [7120-04]

M. Grądkowska, W. Wójcik, Lublin Univ. of Technology (Poland)

712006 Analysis of LP-modes transmission through capillary waveguide [7120-05]

P. Miluski, D. Dorosz, Bialystok Univ. of Technology (Poland)

\section{SESSION 2 METROLOGY OF OPTICAL FIBERS}

712007 Measurements of HB photonic crystal fibers with low temperature sensitivity [7120-06] M. Makara, J. Wojcik, P. Mergo, J. Klimek, K. Skorupski, J. Kopeć, Maria Curie Sklodowska Univ. (Poland)

712008 Hydrostatic pressure effects in photonic liquid crystal fibers [7120-07] M. M. Tefelska, M. Chychłowski, A. Czapla, Warsaw Univ. of Technology (Poland); R. Dąbrowski, Military Univ. of Technology (Poland); S. Ertman, Warsaw Univ. of Technology (Poland); E. Nowinowski-Kruszelnicki, Military Univ. of Technology (Poland); J. Wójcik, Maria Curie Sklodowska Univ. (Poland); T. R. Woliński, Warsaw Univ. of Technology (Poland)

712009 Supercontinuum generation in suspended core microstructured optical fibers [7120-08] P. Mergo, M. Makara, J. Wójcik, K. Poturaj, J. Klimek, K. Skorupski, Maria Curie Sklodowska Univ. (Poland); T. Nasiłowski, Vrije Univ. Brussel (Belgium)

$71200 \mathrm{~A}$ Measurement of modal birefringence and temperature sensitivity of birefringent holey fibers [7120-09]

A. Anuszkiewicz, G. Statkiewicz-Barabach, T. Martynkien, W. Urbańczyk, Wrocław Univ. of Technology (Poland); P. Mergo, M. Makara, J. Wójcik, Marie Curie-Skłodowska Univ. (Poland) 
$7120 \mathrm{OB}$ Measurement of the chromatic dispersion in birefringent microstructured fibers by spectral interferometry [7120-10]

G. Statkiewicz-Barabach, Wroclaw Univ. of Technology (Poland); A. Van Hoeken, Wroclaw Univ. of Technology (Poland) and Kingston Univ. (United Kingdom); M. Mikolajczyk,

W. Urbanczyk, Wroclaw Univ. of Technology (Poland)

\section{SESSION $3 \quad$ TECHNOLOGY OF OPTICAL FIBERS}

7120 OC Sol-gel derived RIB waveguides [7120-11]

P. Karasiński, R. Rogoziński, Silesian Univ. of Technology (Poland)

7120 OD Optical investigations of macro- and microporous silicon antireflection coating [7120-12] J. Jaglarz, Cracow Univ. of Technology (Poland); M. Lipiński, Institute of Metallurgy and Materials Science (Poland); P. Karasiński, Silesian Technical Univ. (Poland)

$7120 \mathrm{OE}$ Time resolved spectroscopy of oxyfluoride glass ceramics activated by $\mathrm{Pr}^{3+}$ ions [7120-13] M. Rozanski, Nicolaus Copernicus Univ. (Poland); M. Środa, AGH Univ. of Science and Technology (Poland); Cz. Koepke, Nicolaus Copernicus Univ. (Poland)

7120 OF Influence of the technological parameters of ion exchange on the repeatability of refractive index profiles of waveguides [7120-14]

R. Rogoziński, Silesian Univ. of Technology (Poland)

$71200 \mathrm{G}$ Thermal and optical properties of $\mathrm{SiO}_{2}-\mathrm{Al}_{2} \mathrm{O}_{3}-\mathrm{PbF}_{2}-\mathrm{ZnF}_{2}-\mathrm{ZnO}_{-} \mathrm{LaF}_{3}-\mathrm{Nd}_{2} \mathrm{O}_{3}$ glasses [7120-15] D. Dorosz, M. Kochanowicz, Bialystok Univ. of Technology (Poland)

$7120 \mathrm{OH} \quad$ Multicore optical fibre doped with neodymium [7120-16]

D. Dorosz, M. Kochanowicz, Bialystok Univ. of Technology (Poland)

7120 ol Tellurite glasses for optical fibre fabrication [7120-17]

M. Reben, J. Wasylak, AGH Univ. of Science and Technology (Poland); D. Dorosz, Bialystok Univ. of Technology (Poland)

\section{SESSION 4 OPTICAL FIBER SENSORS}

7120 0J Multilayer waveguide structures investigated by the generalized $\mathrm{m}$-line spectroscopy [7120-18]

E. Auguściuk, Warsaw Univ. of Technology (Poland)

7120 OK Soft glass photonic crystal fibers for supercontinuum generation [7120-19]

D. Pysz, Institute of Electronic Materials Technology (Poland); R. Buczynski, Warsaw Univ. (Poland); I. Kujawa, Institute of Electronic Materials Technology (Poland); J. Korzeniowski, Warsaw Univ. (Poland); T. Martynkien, Wroclaw Univ. of Technology (Poland); T. Nasilowski, F. Berghmans, H. Thienpont, Vrije Univ. Brussel (Belgium); R. Stepien, Institute of Electronic Materials Technology (Poland)

$7120 \mathrm{OL} \quad$ Fabrication of solid-cladding photonic band gap fiber with air core [7120-20] I. Kujawa, D. Pysz, Institute of Electronic Materials Technology (Poland); R. Buczńyski, A. Filipkowski, J. Nowosielski, Warsaw Univ. (Poland); R. Stępień;, Institute of Electronic Materials Technology (Poland) 
7120 OM Photonic glass: novel method for fabrication of volume 2D photonic crystals [7120-21] I. Kujawa, Institute of Electronic Materials Technology (Poland); A. Filipkowski, Univ. of Warsaw (Poland); D. Pysz, Institute of Electronic Materials Technology (Poland); F. Hudelist, A. Waddie, Heriot-Watt Univ. (United Kingdom); R. Stepien, Institute of Electronic Materials Technology (Poland); R. Buczynski, Univ. of Warsaw (Poland); M. Taghizadeh, Heriot-Watt Univ. (United Kingdom)

$71200 \mathrm{~N} \quad$ Optical fiber Lyot depolarizer analysis based on the modified Mueller-Stokes method [7120-22]

A. W. Domanski, P. Lesiak, Warsaw Univ. of Technology (Poland) and Sensomed Co. (Poland); D. Budaszewski, R. Cieslak, T. R. Wolinski, Warsaw Univ. of Technology (Poland)

712000 Shaped side fibers for angle detection of radiation [7120-23] M. Zajkowski, Bialystok Technical Univ. (Poland)

7120 OP Multipoint optical fiber pressure sensor [7120-24]

J. Kusznier, Bialystok Technical Univ. (Poland)

$71200 Q \quad$ Recovery methods for temperature distribution using fiber Bragg grating [7120-25] W. Wójcik, P. Kisała, G. Mantyka, K. Sobańska, Lublin Univ. of Technology (Poland)

7120 OR Fiber Bragg gratings with very smooth side slopes [7120-26]

J. Helsztyński, L. Lewandowski, Warsaw Univ. of Technology (Poland)

\section{SESSION 5 OPTICAL FIBER APPLICATIONS}

7120 OS Remote measurements system for applications in photonic materials characterization [7120-27]

P. Lesiak, S. Ertman, D. Budaszewski, A. W. Domański, T. R. Woliński, Warsaw Univ. of Technology (Poland); I. Burska, M. Klimczak, R. Piramidowicz, P. Warda, W. Kamiński, Institute of Microelectronics and Optoelectronics (Poland); R. Sitnik, M. Kujawińska, Institute of Micromechanics and Photonics (Poland)

7120 OT Reflectors with directional-mixed reflection properties for application in luminaries with high-power LED diodes [7120-28]

K. Zaremba, Bialystok Technical Univ. (Poland)

7120 OU Multifrequency erbium doped fiber source for UDWDM application [7120-29]

J. Lamperski, A. Dobrogowski, P. Stepczak, Poznan Univ. of Technology (Poland)

7120 OV Parameter optimization of optical fiber coupler in side pumping laser [7120-30] M. Napierała, E. Bereś-Pawlik, Wrocław Univ. of Technology (Poland)

7120 OW Side-pumped double-clad fibre laser designs [7120-31]

E. Bereś-Pawlik, A. Bocheński, M. Napierała, Wrocław Univ. of Technology (Poland);

J. Wójcik, Maria Curie Skłodowska Univ. (Poland)

$71200 \mathrm{X}$ Influence of temperature and length of splicing areas on the loss of joints of single mode telecommunication fibers [7120-32]

M. Ratuszek, Univ. of Technology and Agriculture (Poland) 
7120 OY Nonlinear all-optical switching in multicore fibers [7120-33]

U. A. Laudyn, M. A. Karpierz, Warsaw Univ. of Technology (Poland); J. Wójcik, Maria Curie Sklodowska Univ. (Poland)

$71200 Z$ An automatic protection of a PON feeder based on an optically powered electrooptic switch [7120-34]

W. Wójcik, Z. Lach, A. Smolarz, T. Ławicki, Lublin Univ. of Technology (Poland); A. Tymecki, Telekomunikacja Polska S.A. (Poland)

Author Index 


\section{Conference Committee}

Elżbieta Bereś-Pawlik, Wrocław University of Technology (Poland)

Andrzej Domański, Warsaw University of Technology (Poland)

Jan Dorosz, Conference Chair, Białystok University of Technology (Poland)

Krzysztof Holejko, Warsaw University of Technology (Poland)

Zdzisław Jankiewicz, Institute of Electronic Materials Technology (Poland) and Military University of Technology (Poland)

Leszek R. Jaroszewicz, Military University of Technology (Poland)

Maria Kączka, AGH University of Science and Technology (Poland)

Zygmunt Kuczyński, Institute of Electronic Materials Technology (Poland)

Tadeusz Pusteln, Siliesian University of Technology (Poland)

Jan Rayss, Maria Curie Sklodowska University (Poland)

Antoni Rogalski, Military University of Technology (Poland)

Ryszard S. Romaniuk, Warsaw University of Technology (Poland)

Mieczysław Szustakowski, Military University of Technology (Poland)

Wacław Urbańczyk, Wrocław University of Technology (Poland)

Jan Wasylak, AGH University of Science and Technology (Poland)

Jan Wójcik, Maria Curie Sklodowska University (Poland)

Waldemar Wójcik, Lublin University of Technology (Poland)

Tomasz R. Woliński, Warsaw University of Technology (Poland)

Wieslaw L. Woliński, Honorary Chair, Warsaw University of Technology (Poland) 
Downloaded From: https://www.spiedigitallibrary.org/conference-proceedings-of-spie on 25 Apr 2023

Terms of Use: https://www.spiedigitallibrary.org/terms-of-use 


\section{Opening Address}

Your Magnificence Rector, Honorable Dean, Honorable Professors, Ladies and Gentlemen,

I am greatly honored by your invitation to speak at today's official opening of the 11 th National Conference on Fibers and Their Applications in Białowieża.

It is my great pleasure to welcome all of you who participate in this conference. I welcome experienced researchers who have been witnesses of the conference development since its early beginnings, as well as those who are at the start of their scientific lives, who put their hopes and efforts in the field which is the subject of the conference, and who perhaps are participating in it for the first time. You are those who will be responsible for the further development and progress in the fiber science and technology in our country.

By way of introduction, let me mention the first Conference on Fibers and Their Applications, which was organized by Prof. Adam Smoliński in 1976 in Jablonna. This will allow us to appreciate the progress that has been made in the field in the period for over thirty years.

Professor Smoliński, an outstanding scientist, academic teacher, and science organizer invited four notable scientists from Europe to give lectures at this first conference. Let me cite the titles of the lectures that were delivered by them: (1) W. A. Gambling, United Kingdom, "The ultimate bandwidth performance of optical fibre transmission lines," (2) H. G. Unger, Federal Republic of Germany, "Optical waveguides," (3) B. Crosiniani et al., Italy, "A new method for the measurement of very short optical delays in multimode fibers," and (4) M. Treheux et al., France, "Status of fibre optics research in France."

Six lectures were presented by the polish scientists: (1) B. Paszkowski, "Technology of glass fibers," (2) B. Mroziewicz, "Semiconductor sources of optical signals," (3) W. Woliński, "Integrated optoelectronics," (4) S. Maczyński, "Fotodetectors for optical communication," (5) J. Helsztyński, "Techniques for measurements of radiation sources and detectors" and (6) Z. Szpigler, "Fiber applications for networks."

Opening the first conference, Prof. Janusz Groszkowski, the leading scientific authority and President of the Polish Academy of Sciences (PAS), among other things, said (in free translation) "Fibers as a great scientific discipline will be based on the top achievements in various branches of science and technique including, first of all, these which are par excellence electronics. There is a great potential for development of this field in our country and thus it should be developed." 
As it follows from the proceedings, the first Conference on Fibers and Their Applications concerned mainly multimode fibers operating in the first wavelength window and designed solely for telecommunication. At present, single-mode fibers technology is already fully developed commercially, modern single-mode fibers are characterized by superb parameters for transmission in the third window, and they already have become standards.

During the last dozen or so years, we could also observe rapid progress in new fiber technologies, including fibers for amplification and generation of stimulated radiation, fibers for high-power transmission, and numerous new sophisticated fiber systems for sensing and metrology.

Due to the importance of fibers in the modern science and technology, and due to great possibilities for their practical applications, fibers have been established as a principal area of scientific activities in several research centers in Poland. The program of this conference evidently confirms this. We have an opportunity to become acquainted with the newest results of the investigations concerning various, sometimes unique and even exotic fiber structures revealing new phenomena and properties promising for new applications.

I would like to stress the fact that the successive conferences, organized alternately in Krasnobród by Maria Curie Skłodowska University and Lublin University of Technology and in Białowieża by Białystok University of Technology, gather more and more participants submitting more and more important and advanced papers on their research results.

Integration and intensification of the research activities in the field of fibers, which is an integral part of photonics, is an issue of prime importance for a variety of national interests related to modern science and technology. Considering this fact, the national scientific organizations, Committee on Electronics and Telecommunication of PAS, Polish Committee for Optoelectronics of the Association of Polish Electrical Engineers, and Poland Chapter of SPIE are taking many actions aiming to achieve substantial progress in development of advanced and innovative photonics technologies. At present, a new R\&D program (project) is currently being prepared for coordination and promotion of those research activities that have the biggest chance of being implemented.

In ending my speech, I would like to thank, on my own behalf and on behalf of all participants, the authorities of Białystok Technical University for their support in organizing this conference. I express special thank to the Organizing Committee, and especially to Prof. J. Dorosz and his team for the hard work they put into organizing this conference.

Finally, I would like to wish you inspiring and fruitful discussions over the next few days and I hope that you will also find a little time to rest and enjoy your stay in beautiful Białowieża. 
Let me now declare the 11th National Conference on Fibers and Their Applications open.

Prof. Dr. Hab. Eng. Wiesław L. Woliński

Full Member of PAS

Białystok, 30th of January 2008 
Downloaded From: https://www.spiedigitallibrary.org/conference-proceedings-of-spie on 25 Apr 2023

Terms of Use: https://www.spiedigitallibrary.org/terms-of-use 


\section{Introduction \\ Eleventh Conference on Optical Fibers and Their Applications \\ Białystok, Białowieża, 30 January - 02 February 2008}

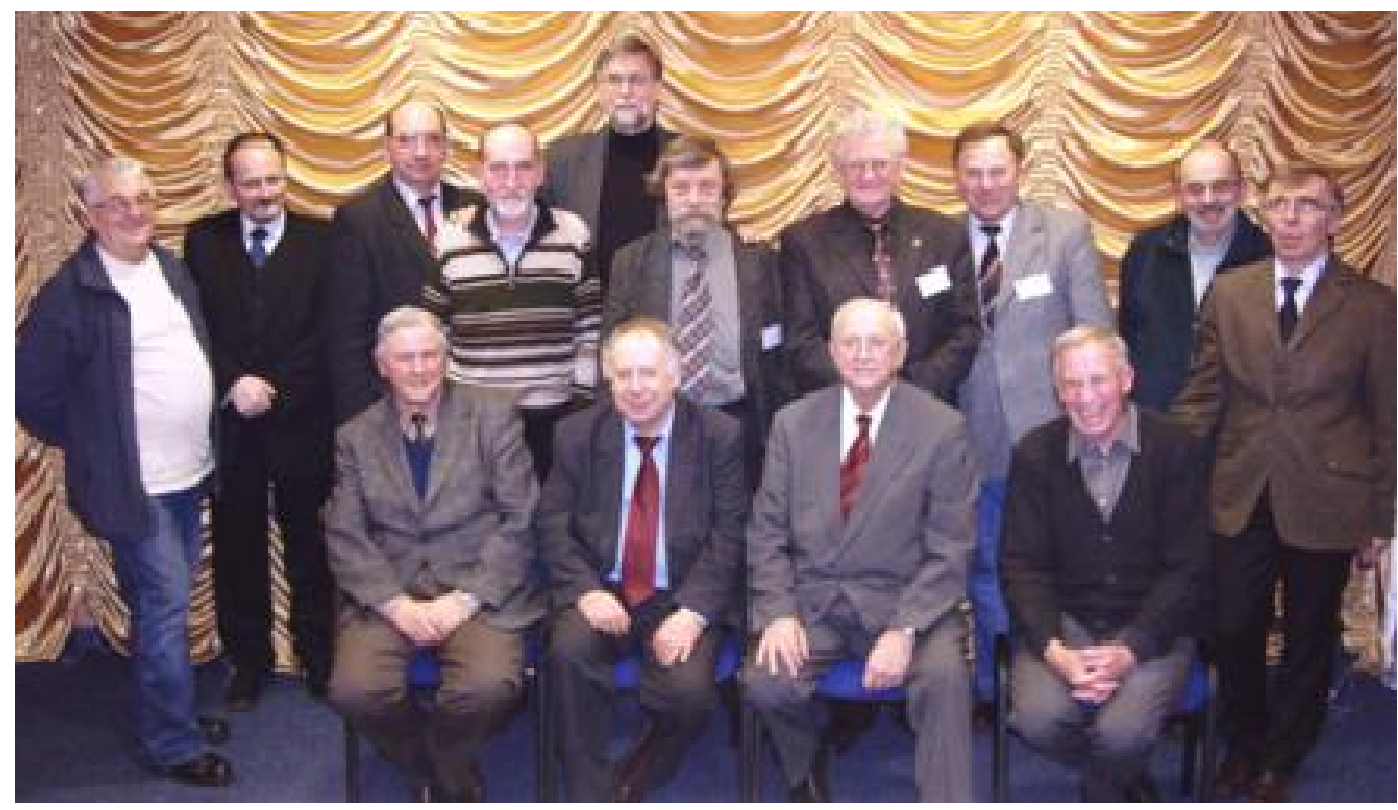

Technical Program Committee of the Conference on Optical Fibers and Their Applications. Seated, left to right: Prof. K. Holejko, Warsaw Univ. of Technology; Prof. J. Dorosz (Conference Chair), Bialystok Univ. of Technology; Prof. W. Woliński, member of Polish Academy of Sciences, Warsaw Univ. of Technology; Prof. A. Rogalski, corresp. Member of Polish Academy of Sciences, Military Academy of Technology; Standing, left to right: Prof. W. Wójcik, Lublin Univ. of Technology; Prof. A. Zajac, Military Academy of Technology and Białystok Univ. of Technology; Prof. A. Domańaki, Warsaw Univ. of Techology; Prof. J. Rayss, Univ. Maria Curie Sklodowska; Prof. R. Romaniuk, Warsaw Univ. of Technology; Dr. Z. Łuczyński, Institute of Electronic Material Technology; Prof. Z. Jankiewicz, Institute of Electronic Material Technology; Prof. J. Wasylak, Academy of Mining and Metallurgy; Dr. M. Ratuszek, Bydgoszcz Univ. of Technology and Agriculture; Prof. T. Pustelny, Silesian Univ. of Technology in Gliwice; Not present: Prof. T. Woliński, Warsaw Univ. of Technology; Dr. J. Wójcik, Univ. Maria Curie Sklodowska. Photo by Dr. Pawel Karasiński of Silesian Univ. of Technology.

During the days of 30 January to 02 February 2008 there was held the Eleventh Conference on Optical Fibers and Their Applications. The Conference was opened at the Electrical Engineering Faculty of Białystok University of Technology and was continued in Białowieża, the Capital of the biggest European Primeval Forest National Park. The conferences of this series have been organized since 1976 from the beginning in the Jabłonna Village Palace near Warsaw, and then ever other year conversely in Białowieża (by Białystok University of Technology, Prof. Jan Dorosz, with emphasis on applications, especially non-telecom ones) and in Krasnobród (by UMCS Lublin, Dr. Jan Wójcik, Prof. J. Rayss, with emphasis on technology and telecom applications). The first conference in Białowieża that focused on non-telecommunication application of optical fibers was held in 1982. During this period the 
conferences in Lublin and then Krasnobród were more focused on technology and metrology of optical fibers supplementing the application and construction topics covered in Białowieża. The conference series on Optical Fibers and Their Applications has been organized in this country for more than 30 years. It was initiated by the late Professors: J. Groszkowski, A. Smoliński, A. Waksmundzki, M. Pluta, and B. Paszkowski. The conferences always gathered the entire national group of optical fiber, as well as optoelectronics experts and a large number of international guests.

The Eleventh Conference was opened by Prof. W. Woliński in the presence of the Rector of Białystok University of Technology. The national expertise in optical fibers has gathered during the recent years at several big organizations, some of them with international roots: Section of Optoelectronics, Committee of Electronics and Telecommunications, Polish Academy of Sciences; Polish Committee of Optoelectronics, Association of Polish Electrical Engineers; Polish Chapter of SPIE. The Latter organization registered in this country as a Society was transformed in 2008 to the Photonics Society of Poland. These organizations cooperate with IEEE Poland Section and LEOS Chapter, Section of Optics by Polish Physical Society and Polish Ceramic Society.

During the conference opening ceremony, Prof. J. Dorosz reminded everybody about the history of Białowieża Conferences. The national experts of guided wave, laser, and semiconductor optoelectronics meeting in Krasnobród, Białowieża, and Świnoujście (Laser Technology Symposium) managed to integrate their activities into the framework of numerable optoelectronics research programs carried out during these years. Realization of these programs led to numerable scientific and technical achievements. These programs also became the impetus for establishing a number of photonic firms in this country. During the recent period, however the dynamics of spin-off establishment has been much lower, which is a subject of concern for these bodies. This decrease is combined with confined money flow to this sector of economy.

The Białowieża Conference gathered over 120 participants, with nearly 80 papers in oral and poster sessions. The biggest groups of papers originated from such university centers active in optoelectronics as: Silesian University of Technology in Gliwice, Białystok, Warsaw and Lublin, as well as UMCS in Lublin. The topical coverage of the Symposium was: materials for optoelectronics - in particular materials for optical fiber technology, fabrication of optical fibers, components and sub-assemblies for optoelectronics, metrology of optical fibers, metrology of optoelectronic components and devices, applications of optical fibers, and education in optoelectronics and photonics.

The following plenary papers touched on very current problems in optoelectronics:

Prof. A. Rogalski, "Quantum dot infrared photodetectors"

Prof. A. Zajac, "Optical fiber lasers of high power - technological and construction requirements"

Prof. J. Rayss, "New polymer materials for applications in photonics"

Prof. T. Pustelny, Optoelectronic structures for applications in sensors.

The technological sessions of the Symposium presented the works from three main national centers where optical fibers are pulled. These are Faculty of Chemistry, University of Maria Curie Skłodowska in Lublin, Faculty of Electrical Engineering at Białystok University of Technology, and Institute of Electronic Materials Technology in Warsaw. A number of research centers in this country and internationally use these optical fibers for optical fiber 
sensors and photonic instrumentation devices. A large group of applications concerned optical fibers filled or impregnated with liquid crystals, which are highly nonlinear optical substances, much more nonlinear than glasses. This group of papers originated from the laboratory of Prof. T. Wolinski and Prof. A. Domański of Warsaw University of Technology. Some of these papers were prepared in cooperation with research groups in Brussels and Canada.

The Symposium organizers have provided very favorable participation conditions for Ph.D. and M.Sc. students, who participated in the Symposium in a large number. The majority of the papers were presented by young researchers, which supports the belief that this branch of technology is vital and promising for future development.

The Editors would like to thank Dr. Maciej Zajkowski from Białystok University of Technology for his devoted help while preparing the papers for this volume.

Jan Dorosz

Ryszard Romaniuk Tomasz Woliński
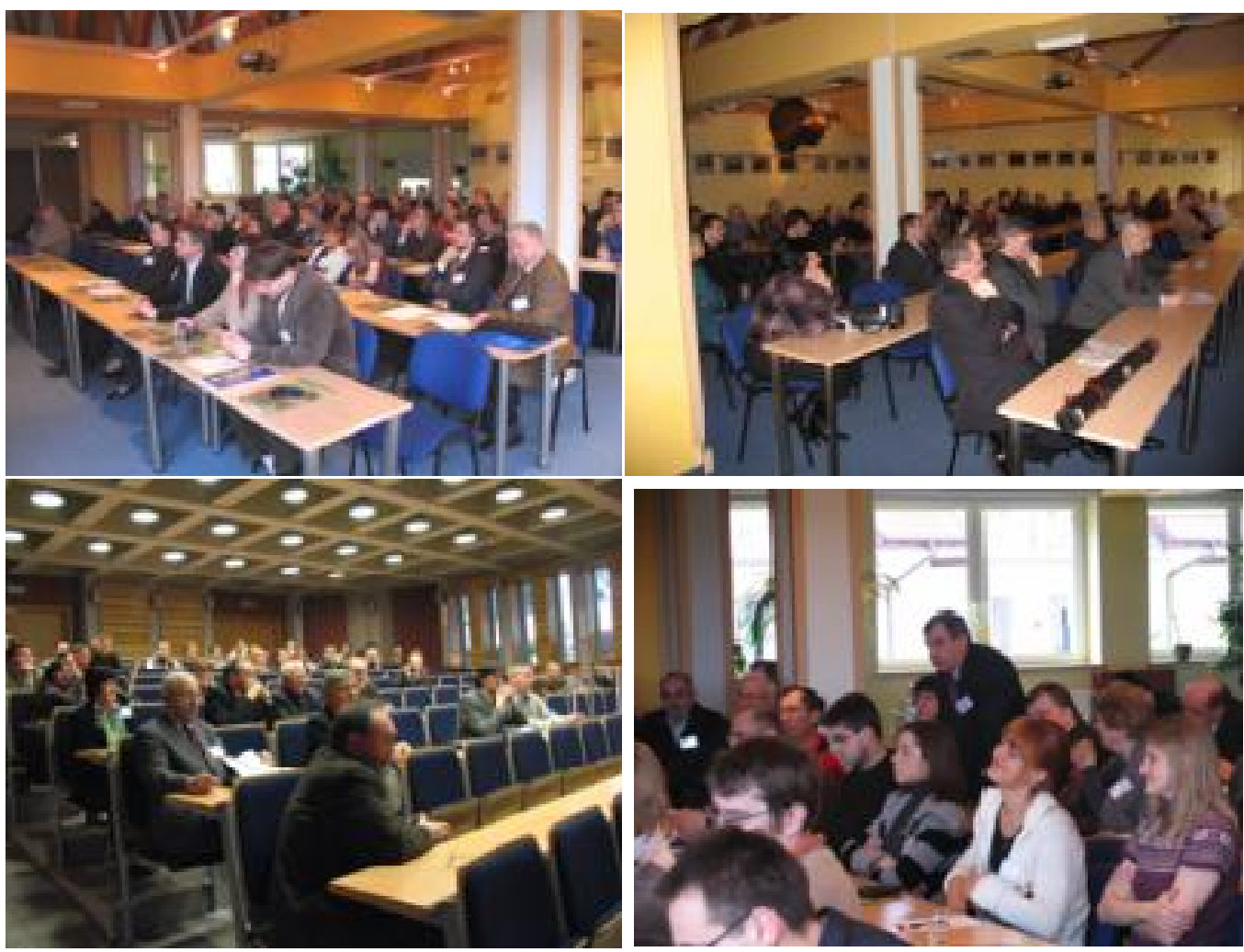


\section{Transformation from SPIE Poland Chapter to Photonics Society of Poland}

\section{SPIE Poland reminiscences, emotional and by no means objective}

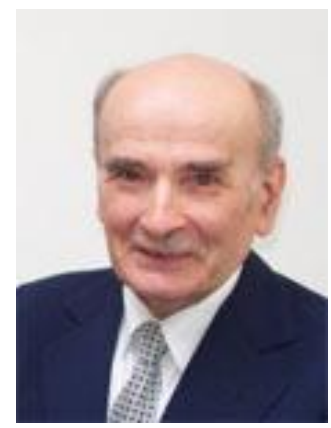

Professor Maksymilian Pluta, 1929-2002, President of SPIE-PL 1990-2002

Motto: Beginnings always seem to be so primitive when viewed retrospectively. Yet they also are viewed with some awe and wonder. Robert (Bob) L. Rodgers, SPIE President 1961-62

Robert L. Woltz said once about SPIE which was also very true about SPIE Poland: "SPIE was started by a small group of people who were dedicated to solving urgent technical and educational problems at their work and were frustrated that they could not do it alone". SPIE Poland Chapter was officially founded in 1988. An official plaque was handed over by SPIE President Harold E. Bennett to SPIE Poland Board. The first official MOU between SPIE and SPIE PL was signed by Joseph Yaver and Prof. Adam Smoliński in 1989.

Before these official steps, some earlier actions led to the establishment of SPIE PL. At the beginning of the 80s, there were a few members of SPIE in Poland including Dr. M. Pawluczyk from the Institute of Applied Optics, and the author of these words. Even earlier, the first conference on Optical Fibers was organized in this country in 1976 in Jablonna. A tabletop exhibit of SPIE literature was organized there. A proposal was forwarded then to SPIE to organize a joint conference in Poland in 1977. This was at the time when the SPIE Proceedings had just crossed the mark of its $200^{\text {th }}$ Volume. It was perhaps too early, and this initiative was not realized. The second conference on Optical Fibers was organized in Poland in February 1979. Again, SPIE literature tabletop exhibit was organized. From the beginning of the 80s, extensive activities of SPIE in Europe could be observed. The first personal contacts between Joe Yaver and myself were established during the following conferences: International Fiber Optics Conference (IFOC) by IGI of Dr. Paul Polishuk in Los Angeles in 1982, and during the SPIE Co-sponsored OPTO Paris. SPIE issued proceedings from the latter, with Volume numbers 403-405, and these volumes had the first papers from Poland. Extensive discussions with Joe Yaver were held also during the European Conference on Optical Communications (ECOC) in Stuttgart in 1984. The first meeting concerning proposal of an MOU between SPIE and SEP - Association of Polish Electrical Engineers was organized during the SPIE Symposium in San Diego in 1985. The participants were SPIE President Lewis Larmore, Joe Yaver, Robert Fisher, Allan Gott, and myself. This meeting was immediately followed by the first SPIE Proceedings volume edited by $M$. Szustakowski and R. Romaniuk with the Vol. number 670 in 1986. The volume contained papers from the 1986 Conference on Optical Fibers in Jabłonna. The first technical exhibit from Poland was organized during the 1986 SPIE Conference in San Diego. 1987 was full of important SPIE events with active participation of fellows from Poland: SPIE Boston, SPIE Hamburg, SPIE Hague, Europto, SPIE Cannes, and the establishment of the European Optical Society. 1988 culminated with the beginning of SPIE Poland Chapter.

Professor M. Pluta chaired the SPIE Poland Chapter as a President from 1990 to 2002. More than 100 SPIE Proceedings volumes were edited during this period. The membership grew to over 300. The office was organized at the Institute of Applied Optics in Warsaw. In 1991, I had a great personal opportunity to spend some time (with my wife) at the SPIE Headquarters in Bellingham. I spend these days there as a sort of a student learning SPIE domestic, in-office, and international procedures. This opportunity was given to me by a 
prestigious President Dwight D. Eisenhower Fellowship which I received from the EEF Foundation, after finishing a short but intense period in the first Solidarity Government of Poland, during the period of the most intense political transformation. During several months of intense stay and study in the USA, I also visited Jarus Quinn and OSA, as well as the IEEE Headquarters. I was awarded for this cooperation an SPIE Fellowship in 1993. These were the solid roots on which we as a photonics community built sound technical cooperation with SPIE. These roots were strong enough to give birth to the idea of a Polish Handsome Girl as a future President of SPIE, which was several years later, Professor Małgosia Kujawińska. These roots were also strong enough to: organize in Poland in 2005 a large SPIE Congress on Optics and Photonics, gathering nearly a thousand researchers and a large technical exhibit, to issue more than 200 SPIE Proceedings volumes, to promote nearly 20 SPIE Fellows, and recently to give birth to the Photonics Society of Poland which evolved directly from the SPIE Poland Chapter.

In 1997, the community organized around the industrial, specialized optical access networks advanced research, astronomy, accelerator physics, synchrotron radiation, free-electron laser, and high-energy physics applications of photonics in Poland decided to start a new series of conferences, completely different from the classical ones. The first Conference on Photonics Applications in Wilga was organized in 1998. The speakers were nearly entirely Ph.D. students active in photonics originating from Poland and from this geographical region. Now we are facing the XXII Conference in Wilga on Photonics Applications, to be held in May 2008. The Conference is held very successfully twice a year. In Wilga, the conference annually gathers more than three-hundred international Ph.D. students. More than 10 thick volumes of SPIE Proceedings were issued from these conferences with more than one thousand papers. More than four thousand Ph.D. and M.Sc. students contributed to this effort. A lot. This is a real contribution of young science to the global effort pot. A series of joint SPIE-IEEE Wilga Symposia is a great success. The rules that led to this success are very simple indeed: gather the best quality presentations and papers (peer reviewed); offer the most exciting topics (for young scientists); extend the best possible umbrella over the meeting - SPIE, IEEE, University, Polish Academy of Sciences, Association of Polish Electrical Engineers; publish the proceedings in the best possible place; gather young people from distant places; make everything very cheap, nearly free, find sponsors, rely on voluntarism of young people; go along three simple rules with young researchers: have fun, have more fun, learn a lot.

\section{Ryszard S.Romaniuk}

Professor at Warsaw University of Technology

SPIE Founder in Poland since 1976

Acknowledgment: I would like to thank personally Mr. Joe Yaver, SPIE Executive Officer, and his wife Agnete Yaver for their continuous sincere and unprecedented support of all actions and contributions by Polish Optical and Photonics Community to the common SPIE efforts. 


\section{Towards the Photonics Society of Poland - The Legacy of SPIE Poland Chapter}

In fall 2002, Professor Tomasz R. Woliński (Warsaw University of Technology) was elected as the SPIE Poland Chapter President and also as the Chair of the newly-elected Board. The Chapter Office and Library returned again to its roots - Warsaw University of Technology. In 2003, the Board started to plan and to organize Optics and Optoelectronics Congress (COO), envisaged for the year 2005.

By all accounts, the first International $\mathrm{COO}$ in 2005 was the biggest ever SPIE event in this geographical region. Held at the Warsaw University of Technology in Poland, COO was a significant success with close to 700 participants (160 students) and 24 exhibitors, and with more than 700 papers which were published in 13 consecutive Proc. of SPIE volumes (59475959). Forty-four countries from all six continents were represented by the participants. This Congress was the first of its kind, sponsored in partnership between the SPIE Poland Chapter and SPIE Europe, with the Chapter volunteers assuming the bulk of the responsibility, including the development of the technical program and all logistics. COO consolidated a number of existing Polish Chapter conferences previously held as standalone events, as well as introducing some new topics. The goal of this Congress was to create a new platform, primarily focused on Eastern and Central Europe, for the dissemination of technical research and applications in optics and optoelectronics and to promote networking amongst international participants.

In 2005, a new MOU between SPIE and the Poland Chapter was signed for the years 20062007, indicating an increasing role of the SPIE-Digital Library. At that time number of Chapter members increased to about 250. In the following years the Chapter - apart from its traditional conference activities - started to consolidate the optics and photonics community in Poland and in this region of Europe, collaborating with Baltic Chapter (SPIE Poland and Baltic Chapters joint Symposium on Optical Technologies in the Baltic Sea region that was held 18-19 May 2006 at Warsaw University of Technology), Russia Chapter (joint conference in 2006 in Olsztyn, Proc. SPIE 6597). In 2007, Poland Chapter became also a partner in the EU-sponsored event LEAP (Linking Europe and Asia in Photonics) that had a culminate point in Beijing, China in November 2007. Annual Maksymilian Pluta Awards were granted four times to Dr. J. Wojcik (2005), Prof. A. Rogalski, (2006), Prof. W. Wolinski (2007), and Prof. M. Szustakowski (2008).

In 2005, in Bellingham, SPIE's Board created and charged a Task Force to review SPIE's Regional Chapter Program. The Task Force completed their work and the Board accepted their recommendation that the Regional Chapter model be replaced with a new program. A consequence of this decision was the dissolution by SPIE of all existing chapter constitutions on 31 December 2007. In his letter of 6 April 2007, Dr. E. Arthurs, SPIE Executive Director wrote to the President of SPIE PL as follows:

"Specifically as regards our longstanding relationship with the Polish Chapter, SPIE has appreciated the opportunity to cooperate with the Polish optics community in developing optics programs, publications and events over the last 22 years. You and your colleagues, both past and present, have built a strong and thriving optics community and we look forward to continuing to work together. We expect that at the close of the Polish Chapter's history, your strong community will continue to meet and network, and we hope you will continue to invite SPIE to participate in your regional activities and events as a formal sponsor." 
On October 18, 2008 an extraordinary General Meeting of the SPIE Poland Chapter members unanimously voted (103 out of 199 SPIE PL members) for transformation of the SPIE Poland Chapter to Photonics Society of Poland. A similar unanimous decision was confirmed by the General Members Meeting on February 25, 2008. The whole registration process of the Photonics Society of Poland is still in progress - it should be officially approved by the National Registration Court. The reaction of SPIE Headquarters was straightforward and enthusiastic:

"I wish you a very successful meeting later this week and assure you of an ongoing close and supportive relationship with the new Photonics Society of Poland. SPIE's leadership recognizes and greatly appreciates the wonderful work done by the chapter members in Poland and I know there is sadness in a way at losing our model chapter, but we believe that this step is the fullest recognition of what the chapter there has done. We wish all our chapters had developed in a way to take a similar step." (Eugene Arthurs)

Photonics Society of Poland (PSP) is presently, with its 215 members (as of February 25, 2008), the largest and the most powerful optics/optoelectronics/photonics organization in Poland. It has already started integration and consolidations activities with Committee of Electronics and Telecommunication/Polish Academy of Sciences (Prof. T. R. Wolinski chairs also its Optoelectronics Section) and with the Committee of Optoelectronics/Society of Polish Electrical Engineers. During the Białowieża conference, on February 1, 2008 there was held a first-ever joint meeting of the boards of these organizations. Photonics Society of Poland proposed to elaborate for the National Center for Research and Development a report on the current status of photonics and optoelectronics in Poland that will create a basis for the Polish Government R\&D policy and further activities in these areas. Once Photonics Society of Poland is officially approved, an opening ceremony will take place in Warsaw, associated with a mini-Symposium. Hopefully things will be progressing well and we should have news of PSP's formal existence within a short time.

\section{Tomasz Woliński}

President of SPIE-PL (2002-2007) and PSP (2007-present)

\section{Andrzej Domański}

Treasurer of SPIE-PL (1988-2007) and PSP (2007-present)

Ryszard Romaniuk

Board Member of SPIE-PL (1988-2007) and PSP (2007-present)

Warsaw University of Technology 
Downloaded From: https://www.spiedigitallibrary.org/conference-proceedings-of-spie on 25 Apr 2023

Terms of Use: https://www.spiedigitallibrary.org/terms-of-use 